\title{
Video Profile Program Berita Klik Indonesia Malam Sebagai Media Informasi
}

\author{
Muhammad Arief Mujahid*1, Rudi Septianto Nugroho ${ }^{2}$, Niken Rizqyah ${ }^{3}$ \\ ${ }^{* 1}$ Program Studi Teknik Informatika Fakultas Sains dan Teknologi Universitas Raharja \\ ${ }^{2}$ Program Studi Manajemen Informatika Fakultas Sains dan Teknologi Universitas Raharja \\ ${ }^{3}$ Program Studi Sistem Informasi Fakultas Sains dan Teknologi Universitas Raharja \\ Email : arief.mujahid@ raharja.info ${ }^{* 1}, \underline{\text { rudi@ raharja.info }}^{2},{\text { niken.rizqyah@ } \text { raharja.info }^{3}}^{3}$
}

\begin{abstract}
Abstrak
Program berita Klik Indonesia Malam yang ditayangkan setiap hari di stasiun televisi milik pemerintah yaitu TVRI (Televisi Republik Indonesia) menjadi salah satu program berita yang diminati oleh masyarakat Indonesia karena menyajikan berita yang up to date mengenai informasi seputar wilayah Indonesia. Oleh karena itu perlu sebuah strategi agar program berita Klik Indonesia Malam tetap menjadi program berita yang di nantikan oleh masyarakat diseluruh wilayah di Indonesia. Dengan melalui sebuah media rancangan video profile yang menjelaskan mengenai program berita Klik Indonesia Malam sebagai media untuk memberikan informasi kepada masyarakat agar tertarik untuk melihat program berita tersebut. Dengan menggunakan metode sebagai proses penyusunan untuk penelitian ini adalah metode observasi, metode wawancara dan metode studi pustaka Sebagai media penunjang dalam rancangan video tersebut maka didukung beberapa software diantaranya adalah adobe illustrator cc 2019, adobe premiere pro cc 2019 dan adobe after effect cc 2019. Dengan rancangan media tersebut maka didapatkan kesimpulan yaitu dengan rancangan media berbentuk video maka dapat memberikan informasi secara lengkap mengenai program berita Klik Indonesia Malam yang di ditayangkan oleh TVRI.
\end{abstract}

Kata Kunci - Berita, Informas, Klik Indonesia Malam

\begin{abstract}
The news program Klik Indonesia Malam, which is broadcast every day on the government-owned television station, namely TVRI (Televisi Republik Indonesia), is one of the news program that are of interest to the Indonesian people because it provides up to date news regarding information about Indonesian territory. Therefore we need a strategy so that the news program Klik Indonesia Malam remains a news program that is eagerly awaited by people in all regions in Indonesia. Through a media video profile that explains the news program Klik Indonesia Malam as a medium to provide information to the public to be interested in seeing the news program. Using the method as a compilation process for this research is the observation method, the interview method and the literature study method. As supporting media in the video design, several software are supported including Adobe Illustrator cc 2019, Adobe Premiere Pro cc 2019 and Adobe After Effects cc 2019. With the media video, the conclusion is that with the video of the media in the form of a video, it can provide complete information about the news program Klik Indonesia Malam which is broadcast by TVRI.
\end{abstract}

Keywords - News, Information, Klik Indonesia Malam

\section{PENDAHULUAN}

Televisi menjadi sebuah media massa yang diminati oleh masyarakat. Dengan televisi maka masyarakat akan mendapatkan informasi up to date dengan menampilkan informasi 
dengan visual bergerak (video) yang menampilkan text, visual dan suara yang dapat didengar karena isi informasi akan tersampaikan dengan baik kepada audience.

Klik Indonesia Malam menjadi program berita unggulan pada jam prime time karena menampilkan informasi secara lengkap mengenai informasi di wilayah Indonesia secara up to date tentang informasi sosial, ekonomi, politik, budaya, olahraga dan lainnya. Masyarakat pun menantikan program berita Klik Indonesia Malam karena program berita tersebut menjadi program berita unggulan sehingga di nantikan oleh masyarakat.

Berita menjadi kebutuhan informasi untuk masyarakat. Berita adalah laporan tentang fakta atau ide yang bermassa, yang dapat menarik perhatian pembaca karena sesuatu yang luar biasa penting. ${ }^{[1]}$ Dengan adanya berita akan membawa masyarakat menjadi terbawa dengan suatu informasi yang disampaikan dari isi berita tersebut. Dengan berita yang up to date setiap harinya maka sebuah media massa menjadi konsumsi informasi untuk masyarakat. Media massa adalah penggunaan komunikasi dengan menggunakan skala media yang besar. ${ }^{[2]}$

Dengan melihat media tersebut maka tujuan dari rancangan media video ini adalah untuk memberikan informasi mengenai program berita Klik Indonesia Malam kepada masyarakat agar program berita tersebut menjadi program berita yang selalu memberikan informasi secara up to date mengenai informasi di wilayah indonesia secara cepat. Dalam video tersebut pun menampilkan informasi aktivitas yang dilakukan di lingkup mengenai program berita Klik Indonesia Malam yang di tayangkan oleh TVRI.

Dengan dukungan media video yang berkualitas maka perlu menggunakan beberapa software penunjang agar video yang dihasilkan memiliki kualitas yang baik yaitu Adobe Premiere Pro CC 2019 yang digunakan sebagai software untuk mengolah video yang biasa digunakan oleh beberapa rumah produksi dan televisi untuk mengolah video menjadi sebuah video yang berkualitas ${ }^{[3]}$ serta Adobe After Effect CC 2019 digunakan untuk menunjang pembuatan media $2 \mathrm{D}$ dengan menggunakan template yang sesuai dengan kebutuhan media ${ }^{[4]}$.

\section{METODE PENELITIAN}

Metode penelitian digunakan sebagai acuan dalam penelitian untuk mendapatkan beberapa data yang terkait dengan penyusunan penelitian tersebut adalah :

1. Metode Observasi

Metode observasi tersebut dilakukan sebagai metode untuk mendapatkan beberapa data yang dibutuhkan terkait dengan penelitian dalam melakukan perancangan video yaitu TVRI namun dengan terfokuskan penelitian pada program berita Klik Indonesia Malam.

2. Metode Wawancara

Metode wawancara tersebut dilakukan sebagai mendapatkan sumber data secara langsung dengan menyiapkan pertanyaan yang terkait dengan kebutuhan penelitian untuk melakukan perancangan media video tersebut.

3. Studi Pustaka

Metode studi pustaka tersebut dilakukan sebagai mengumpulkan beberapa data yang diperlukan dan bersumber dari jurnal, buku dan media lainnya yang diperlukan sebagai acuan dalam melakukan penelitian.

\section{Literature Review}

Literature Review merupakan istilah yang digunakan untuk merujuk pada metodologi penelitian atau riset tertentu dan pengembangan yang dilakukan untuk mengumpulkan serta mengevaluasi penelitian yang terkait pada fokus topik tertentu. Oleh karena itu terdapat 5 artikel yang memiliki keterkaitan dengan penelitian ini adalah : 
Penelitian yang dilakukan oleh Edison dan Reski Pulpi Tambes. Dalam kutipan jurnal Pemikiran Islam. (2019:15) ${ }^{[5]}$ dengan judul penelitian "Peran Editor Video dalam Produksi Program Sembang Malam di Ceria Tv Pekanbaru". Komunikasi massa harus bersebelahan dengan gatekeeper, disebut sebagai gatekeeper dalam suatu penugasan yaitu penanggung jawab pemilihan, pemilihan, pengubahan, dan penanggung jawab yang nantinya akan disiarkan ke audiens.

Penelitian yang dilakukan oleh Wulandari dan Lukman Hakim. Dalam kutipan jurnal Islamic Civilization (2019:96) ${ }^{[6]}$ dengan judul penelitian "Produksi Program Jurnal 9 pada TV9 dalam Prespektif Media Islam" berita yang disampaikan merupakan berita yang efektif dan efesien, menjadi seorang wartawan yang disiplin dan bertanggung jawab sesuai dengan agama islam.

Penelitian yang dilakukan oleh Roy dan Indah Suryawati. (2018:1 $)^{[7]}$ dengan judul penelitian "Strategi Produser dalam Mempertahankan Program Acara "D'sign" di Net TV". Program TV merupakan sebuah acara yang banyak di tonton orang adalah untuk dapat dinikmati dalam bentuk audio visual. Menariknya sebuah acara TV bergantung pada kemasan.

Penelitian yang dilakukan oleh Ningsih, dkk. Dalam kutipan jurnal Icit. (2017:42) ${ }^{[8]}$ dengan judul penelitian "Produksi Program Music Chamber dalam Bentuk Video Documenter Pada PT. Mata Air Inspirasi (SWANA FMTV)" PT. Mata Air Inspirasi (SWARNA FMTV) saat ini bergerak pada konten televisi digital. Tayangan yang sudah ada sebelumnya di SWARNA FMTV yaitu jenis konten program talkshow.

Penelitian yang dilakukan oleh Nensir, dkk. Dalam kutipan jurnal Wiashiyah. $(2020: 213)^{[9]}$ dengan judul penelitian "Produksi Siaran Langsung Tvone Biro Makassar dalam Program Apa Kabar Indonesia Pagi Edisi September 2019”. Studi ini mengkaji proses produksi siaran langsung (live report). Tujuannya untuk mengetahui tahapan proses produksi siaran langsung (live report) dan menjelaskan lebih lanjut faktor-faktor terkait penghambat produksi siaran langsung (live report) biro tvOne Makassar.

\section{HASIL DAN PEMBAHASAN}

\subsection{Pre Production}

Metode pre production (pra produksi) adalah tahapan proses penyusunan dari naskah, script writing dan membuat rundown serta menyiapkan beberapa crew agar proses tahapan produksi dapat berjalan dengan baik sesuai dengan yang diinginkan.

1. Ide atau gagasan

Ide atau gagasan adalah sebuah tahapan awal sebelum memulai sebuah rancangan media video agar video dapat dinikmati dan mudah dipahami oleh masyarakat. Oleh karena itu perlu sebuah tahapan ide atau gagasan agar video pun ketika sampai di masyarakat akan mudah dipahami dengan ide dan konsep video yang menarik. Dengan sebuah ide yang menarik serta isi pesan yang mudah tersampaikan kepada masyarakat maka video program berita Klik Indonesia Malam akan menjadi sebuah video informasi yang akan menarik untuk dilihat oleh masyarakat. Sehingga informasi program berita Klik Indonesia Malam mudah untuk dipelajari dan menjadi sarana edukasi bagi masyarakat.

2. Sinopsis atau cerita

Sinopsis adalah bagian dari alur cerita yang menghubungkan jalan cerita pertama hingga terakhir, dan digabungkan sehingga menjadi satu jalan cerita yang menarik. Sinopsis pun perlu dipersiapkan sebelum proses produksi dilakukan sebagai sebuah gambaran alur video yang akan dibuat. Berikut ini adalah sinopsis pada rancangan media video informasi program berita Klik Indonesia Malam :

Tampilan awal untuk video dengan tema video informasi proses produksi program berita Klik Indonesia Malam adalah menampilkan logo TVRI sebagai logo identitas dari sebuah stasiun televisi. Maka dilanjutkan dengan tampilan video motion graphic menampilkan 
masyarakat sedang melihat berita yang dimaksudkan sebagai gambaran bahwa berita yang berkualitas pun perlu sebuah proses persiapan produksi yang matang. Selanjutnya menampilkan gambaran sebuah proses produksi dari suatu program berita. Selanjutnya adalah video menampilkan ruangan penyiaran yang menjelaskan setelah seluruhnya sudah dicek dan dapat berjalan dengan baik maka persiapan untuk live atau on air. Selanjutnya menampilkan ruangan penyiar berita yang menjelaskan Maka berita mulai disiarkan dan disampaikan kepada masyarakat. Selanjutnya menampilkan Menampilkan image proses liputan di lapangan yang menjelaskan Sudah mengetahui kan proses produksi berita yang berjalan selama ini ?. tahapan video selanjutnya adalah Menampilkan presenter berita datang ke ruangan kantor yang menjelaskan butuh persiapan yang matang agar berita yang disampaikan kepada masyarakat dapat berkualitas.

3. Narasi

Narasi adalah sebuah penggalan paragraf dalam sebuah rangkaian yang telah di jabarkan sesuai dengan urutan. Narasi pun menjadi sebuah cerita singkat dalam sebuah video tersebut. Berikut ini narasi yang dijelaskan pada media rancangan media video program berita Klik Indonesia Malam :

"Sebuah berita yang berkualitas perlu sebuah proses persiapan produksi yang matang kepada masyarakat seluruh wilayah Indonesiall Bagaimana sebuah berita agar dapat tersampaikan dengan baik kepada masyarakat? program berita Klik Indonesia Malam adalah sebuah program berita yang tayang di TVRI setiap pukul 18.00 WIB// Sebelum live on air/ tahapan selanjutnya adalah cek VD sebelum on air// Diruangan ini seluruhnya akan terkoneksi dengan ruangan studio dimana presenter akan menyampaikan berita kepada masyarakat// Seperti pengecekan VD/ Telefromter/Video Playout dan audioman// Seteleha seluruhnya sudah melalui pengecekan dan dapat berjalan dengan baik maka persiapan untuk live atau on air/l Maka berita mulai disiarkan dan disampaikan kepada masyarakat// butuh persiapan yang matang agar berita yang disampaikan kepada masyarakat dapat berkualitas. Sehingga masyarakat mendapatkan informasi yang up to date setiap harinya//"

4. Pembuatan Storyboard

Storyboard adalah sebuah teknik shooting management. Disini dibuat daftar pengambilan gambar pada setiap adegan, dan divisualisasikan dalam bentuk sketsa gambar atau storyboard jika diperlukan. Berikut ini adalah storyboard rancangan video informasi program berita Klik Indonesia Malam :

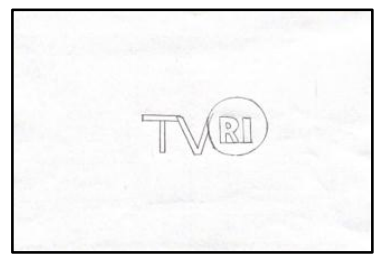

Gambar 1. Scene 1 Menampilkan Logo TVRI

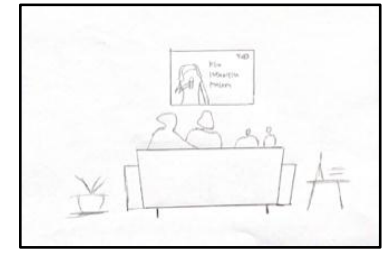

Gambar 2. Scene 2 Menampilkan Masyarakat Melihat Berita 


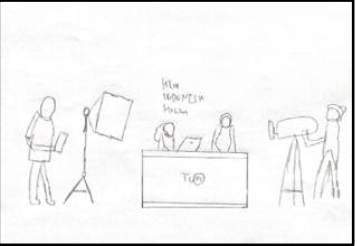

Gambar 3

Scene 4 Menampilkan Gambaran Penyiar Berita

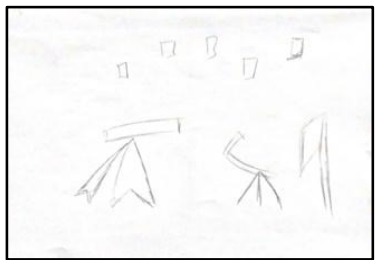

Gambar 5

INT / Scene 13 Menampilkan Ruangan Studio Penyiar Berita / Full Shoot

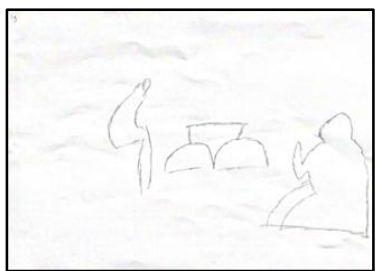

Gambar 7

EXT / Scene 19 Menampilkan Proses Produksi di Lapangan / Full Shoot

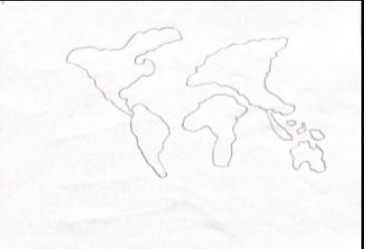

Gambar 4

INT / Scene 18 Menampilkan

Ruangan Studio Penyiaran / Medium Shoot

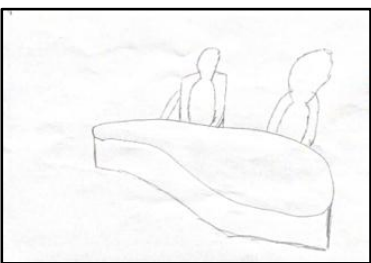

Gambar 6

INT / Scene 7 Menampilkan Ruangan News Room / Medium Shoot

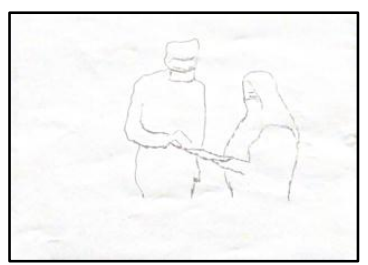

Gambar 8

INT/ Scene 20 Menampilkan

Presenter Ke Ruangan News Room / Medium Shoot

\section{Script Writing}

Script writing adalah rancangan penulisan naskah secara detail yang di dalamnya berupa ide atau gagasan yang sudah di buat pada sinopsis menjadi sebuah konsep yang menarik. Dengan pembuatan script writing maka susunan video dengan narasi yang akan ditampilkan akan disesuaikan dengan gambar. Oleh karena itu berikut ini adalah susunan script writing pada rancangan media video informasi program berita Klik Indonesia Malam:

Tabel 1. Script Writing

\begin{tabular}{|c|c|c|}
\hline No & Visual & Audio \\
\hline 1 & Menampilkan Logo TVRI & Music \\
\hline 2 & $\begin{array}{l}\text { Menampilkan video motion graphic } \\
\text { masyarakat melihat berita }\end{array}$ & $\begin{array}{l}\text { Sebuah berita yang berkualitas perlu sebuah } \\
\text { proses persiapan produksi yang matang// }\end{array}$ \\
\hline 3 & $\begin{array}{l}\text { Menampilkan video motion graphic } \\
\text { gambaran berita }\end{array}$ & $\begin{array}{l}\text { Bagaimana sebuah berita agar dapat } \\
\text { tersampaikan dengan baik kepada masyarakat } \\
\text { ?// }\end{array}$ \\
\hline 4 & $\begin{array}{l}\text { Menampilkan ruangan news room Klik } \\
\text { Indonesia Malam }\end{array}$ & $\begin{array}{l}\text { Proses pertama adalah melakukan rapat } \\
\text { redaksi, rapat dilakukan sebagai bahan untuk } \\
\text { menampilkan berita yang sedang popular di }\end{array}$ \\
\hline
\end{tabular}




\begin{tabular}{|c|l|l|}
\hline 5 & Menampilkan ruangan studio room & $\begin{array}{l}\text { Indonesia// } \\
\text { Diruangan ini seluruhnya akan terkoneksi } \\
\text { dengan ruangan studio dimana presenter akan } \\
\text { menyampaikan berita// }\end{array}$ \\
\hline 6 & Menampilkan ruangan penyiar berita & $\begin{array}{l}\text { Setelah seluruhnya sudah dicek dan dapat } \\
\text { berjalan dengan baik maka persiapan untuk } \\
\text { LIVE atau ON AIR// }\end{array}$ \\
\hline 7 & $\begin{array}{l}\text { Menampilkan image proses lipuran di } \\
\text { lapangan }\end{array}$ & $\begin{array}{l}\text { Sudah mengetahui kan proses produksi berita } \\
\text { yang berjalan selama ini ?// }\end{array}$ \\
\hline newampilkan presenter datang ke ruang & $\begin{array}{l}\text { Butuh persiapan yang matang agar berita yang } \\
\text { disampaikan kepada masyarakat dapat } \\
\text { berkualitas// }\end{array}$ \\
\hline
\end{tabular}

6. Rundown

Rundown perlu disusun agar rancangan video pun dapat disusun dan disesuaikan antara video yang akan ditampilkan dengan total durasi dapat berjalan dengan waktu yang sama. Oleh karena itu berikut ini susunan rundown dalam rancangan media video informasi program berita Klik Indonesia Malam :

Tabel 2. Rundown

\begin{tabular}{|c|c|c|c|c|c|}
\hline No & Scene & Lokasi & Durasi & $\begin{array}{l}\text { INT / } \\
\text { EXT }\end{array}$ & Deskripsi \\
\hline 1 & Scene 1 & - & $\begin{array}{l}\text { 00:00:00 } \quad \text { s/d } \\
00: 06: 00\end{array}$ & - & Menampilkan Logo TVRI \\
\hline 2 & Scene 2 & - & $\begin{array}{l}\text { 00:06:00 } \quad \text { s/d } \\
00: 00: 14\end{array}$ & - & $\begin{array}{l}\text { Menampilkan video motion } \\
\text { graphic masyarakat melihat } \\
\text { berita }\end{array}$ \\
\hline 3 & Scene 4 & - & $\begin{array}{ll}00: 00: 21 & \mathrm{~s} / \mathrm{d} \\
00: 00: 28 & \end{array}$ & - & $\begin{array}{l}\text { Menampilkan video motion } \\
\text { graphic gambaran berita }\end{array}$ \\
\hline 4 & Scene 7 & $\begin{array}{l}\text { Ruang news } \\
\text { room }\end{array}$ & $\begin{array}{ll}00: 00: 44 & \text { s/d } \\
00: 00: 52 & \end{array}$ & INT & $\begin{array}{l}\text { Menampilkan ruangan news } \\
\text { room Klik Indonesia Malam }\end{array}$ \\
\hline 5 & Scene 13 & $\begin{array}{l}\text { Ruangan } \\
\text { studio room }\end{array}$ & $\begin{array}{ll}00: 01: 33 & \text { s/d } \\
00: 01: 43 & \end{array}$ & INT & $\begin{array}{l}\text { Menampilkan ruangan studio } \\
\text { room }\end{array}$ \\
\hline 6 & Scene 18 & $\begin{array}{l}\text { Ruangan } \\
\text { studio room }\end{array}$ & $\begin{array}{ll}00: 02: 12 & \text { s/d } \\
00: 02: 32 & \end{array}$ & INT & $\begin{array}{ll}\text { Menampilkan } & \text { ruangan } \\
\text { penyiar berita } & \end{array}$ \\
\hline 7 & Scene 19 & 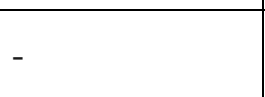 & $\begin{array}{ll}00: 02: 33 & \text { s/d } \\
00: 02: 43 & \end{array}$ & EXT & $\begin{array}{l}\text { Menampilkan image proses } \\
\text { lipuran di lapangan }\end{array}$ \\
\hline 8 & Scene 20 & $\begin{array}{l}\text { Ruangan news } \\
\text { room }\end{array}$ & $\begin{array}{ll}00: 02: 44 & \mathrm{~s} / \mathrm{d} \\
00: 03: 00 & \end{array}$ & INT & $\begin{array}{l}\text { Menampilkan presenter } \\
\text { datang ke ruang news room }\end{array}$ \\
\hline
\end{tabular}

7. Penyusunan Crew

Berikut ini adalah susunan crew dalam rancangan media video informasi program berita Klik Indonesia Malam adalah :

Tabel 3. Susunan Crew

\begin{tabular}{|c|l|l|}
\hline No & \multicolumn{1}{|c|}{ Nama } & \multicolumn{1}{c|}{ Jabatan } \\
\hline 1 & Muhammad Arief Mujahid & Sutradara \& cameramen \\
\hline 2 & Rudi Septianto Nugroho & Cameramen \\
\hline
\end{tabular}


Print ISSN: 2723-1992

Online ISSN: 2723-200X

\begin{tabular}{|l|l|l|}
\hline 3 & Niken Rizqyah & Editing Video \& Dubbing \\
\hline
\end{tabular}

8. Analisa Perancangan Media

Untuk mengolah sebuah video yang memiliki kualitas baik dan dapat dinikmati oleh masyarakat secara luas maka diperlukan dukungan tunjangan software yaitu Adobe Illustrator CC 2019, Adobe Premiere Pro CC 2019 and Adobe After Effects CC 2019.

9. Time Schedule

Agar proses produksi berjalan dengan sesuai dengan hasil dan capaian yang diinginkan maka perlu disusun time schedule sebagai acuan untuk melakukan penayangan rancangan media video. Berikut ini adalah time schedule dari penelitian yang dilakukan oleh penulis :

Tabel 4. Time Schedule

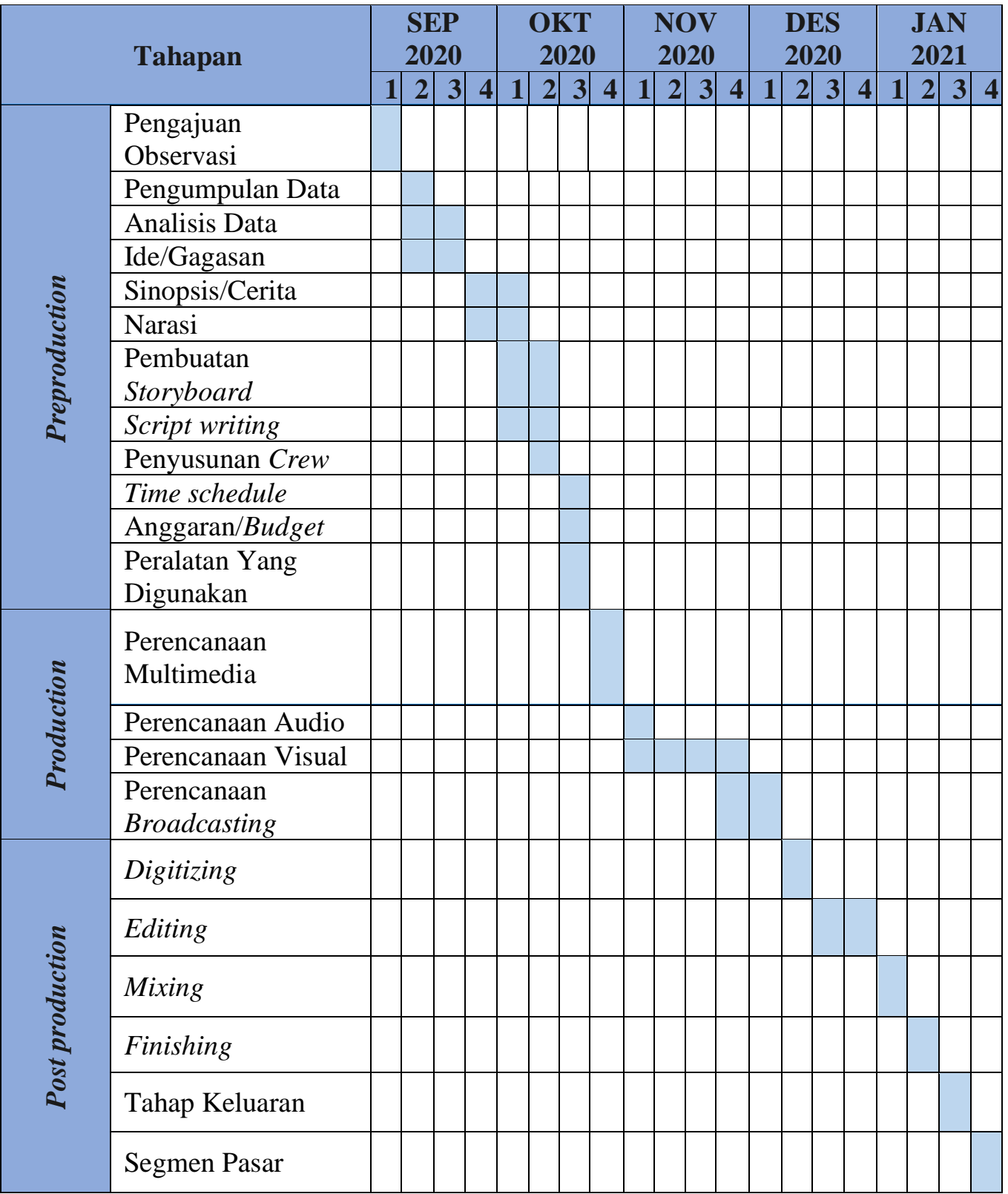


10. Alat yang Digunakan

Berikut ini beberapa peralatan yang digunakan dalam rancangan media video tersebut adalah :

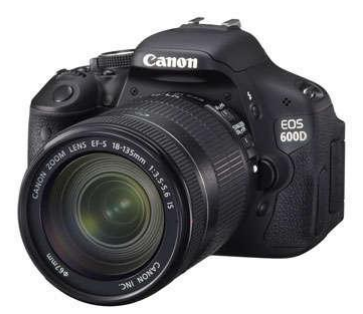

Gambar 9 Kamera Canon EOS $600 D$

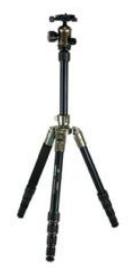

Gambar 11 Tripod

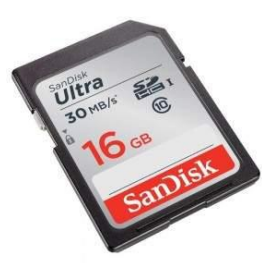

Gambar 10 Memory Sandisk Ultra $16 G B$

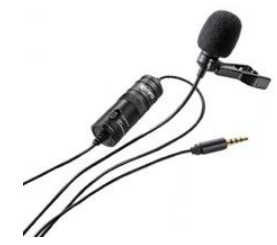

Gambar 12 Microphone

\subsection{Production}

Production atau tahapan produksi adalah tahapan pengambilan data yang dibutuhkan sesuai script dan storyboard. Kondisi seperti ini crew dan actor banyak berkomunikasi dilapangan produksi. Tahapan produksi ini adalah tahapan dimana seluruh proses yang sudah disiapkan pada tahapan pra produksi sudah disiapkan dan sudah disusun sesuai dengan konsep video yang diinginkan serta narasi dan script writing yang sudah disusun. Sehingga tahapan ini sudah memasuki proses untuk pengambilan gambar video.

\section{Program Visual}

1. Tampilan Logo TVRI

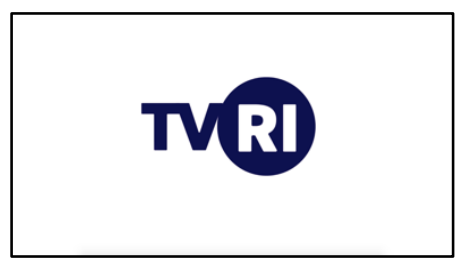

Gambar 9

Scene 1 Menampilkan Logo TVRI
2. Tampilan Masyarakat Melihat Berita

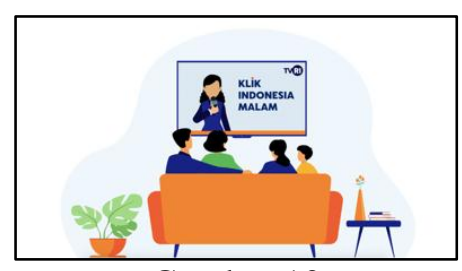

Gambar 10

Scene 2 Menampilkan Masyarakat Melihat Berita 
3. Menampilkan Gambaran Penyiar Berita

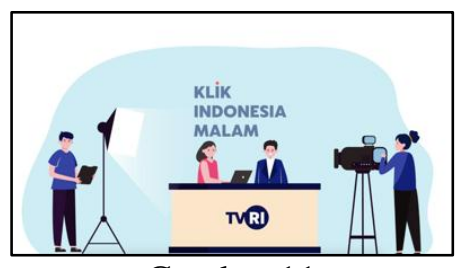

Gambar 11

Scene 4 Menampilkan Gambaran Penyiar Berita

5. Menampilkan Ruangan Studio Penyiar Berita

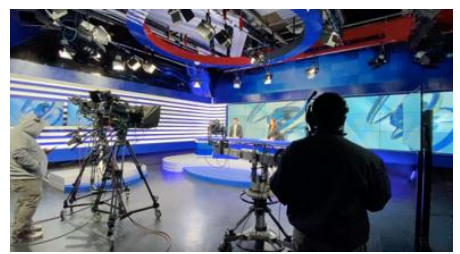

Gambar 13

INT / Scene 13 Menampilkan Ruangan Studio Penyiar Berita / Full Shoot

7. Menampilkan Proses Liputan di Lapangan

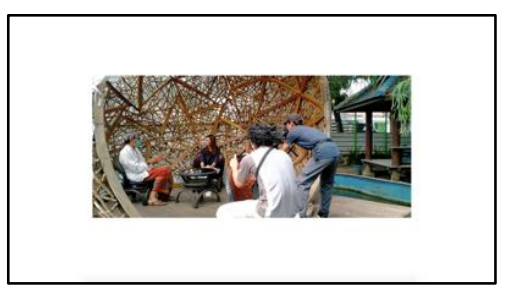

Gambar 15

EXT / Scene 19 Menampilkan Proses

Produksi di Lapangan / Full Shoot
4. Menampilkan Ruangan News Room

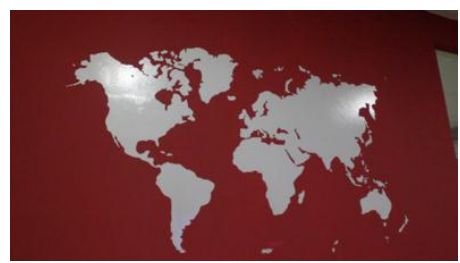

Gambar 12

INT/ Scene 7 Menampilkan Ruangan News Room / Medium Shoot

6. Menampilkan Ruangan Studio Penyiaran

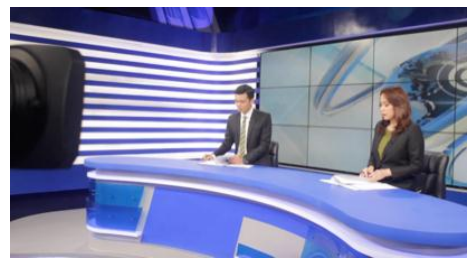

Gambar 14

INT / Scene 18 Menampilkan Ruangan Studio Penyiaran / Medium Shoot

8. Menampilkan Presenter ke Ruangan News Room

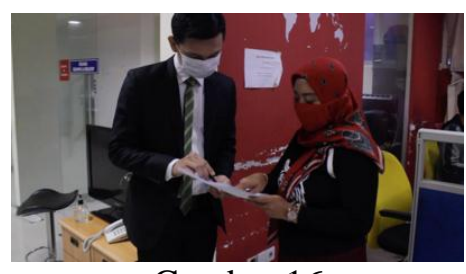

Gambar 16

INT / Scene 20 Menampilkan Presenter Ke Ruangan News Room / Medium Shoot

\subsection{Post production}

Postproduction perlu dilakukan sebagai suatu proses tahapan akhir untuk mengolah video tersebut yang diharapkan menjadi sebuah media video dengan hasil akhir yang diharapkan dan sesuai dengan konsep yang diinginkan bersama. Sehingga dengan rancangan media tersebut diharapkan masyarakat pun ingin mengetahui dan dapat mempelajari mengenai informasi program berita Klik Indonesia Malam.

\section{Digitizing}

Digitizing adalah proses pemindahan hasil dari tahapan produksi ke dalam perangkat media penunjang yaitu laptop untuk selanjutnya video tersebut untuk diproses kedalam tahapan seleksi. Dari tahapan seleksi maka akan di pilih video dengan pengambilan kualitas yang terbaik sehingga video tersebut akan diolah dan digabungkan dengan video lainnya sehingga hasil akhir video sesuai dengan yang diinginkan. 


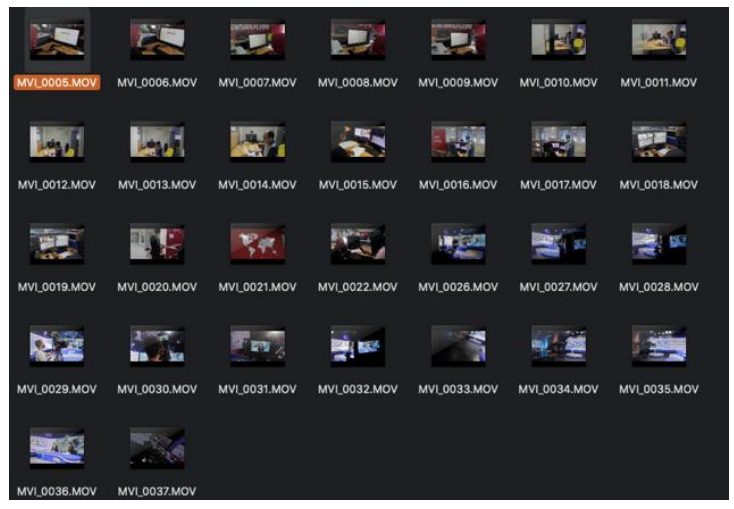

2. $\quad$ Editing

Gambar 17. Proses Digitizing

Editing adalah tahapan seluruh video yang sudah diseleksi yang sudah memiliki kualitas baik. Maka editing video adalah proses penggabungan video yang sudah disusun secara baik di script writing sehingga menciptakan alur video yang sesuai dengan yang dituliskan dan akan digabungkan dengan beberapa unsur lainnya yang akan digunakan dalam rancangan video tersebut.

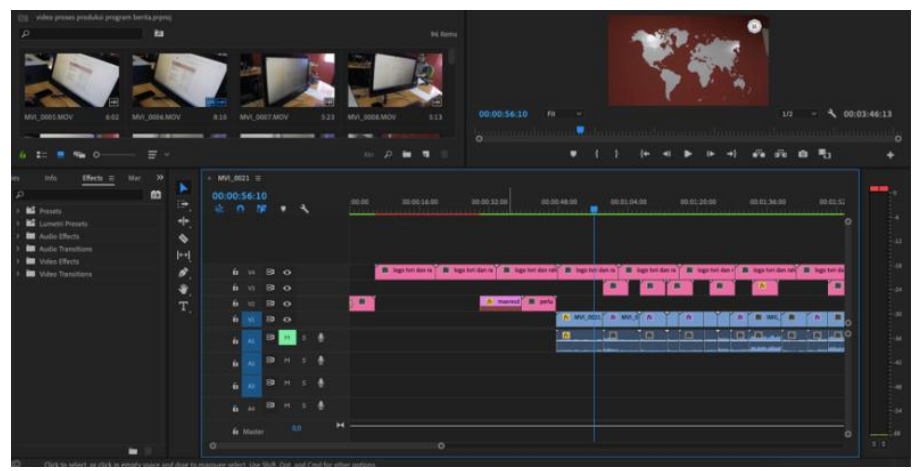

Gambar 18 Proses Editing

3. $\quad$ Mixing

Mixing adalah tahapan penggabungan backsound dengan dubbing. Pada tahapan ini perlu untuk mencocokan antara gambar pada timeline dengan suara dubbing sehingga terdapat kesamaan antara gambar dengan narasi yang telah dituliskan. Mixing akan menentukan kesinambungan gambar dengan dubbing yang disesuaikan dari narasi yang telah dibuat.

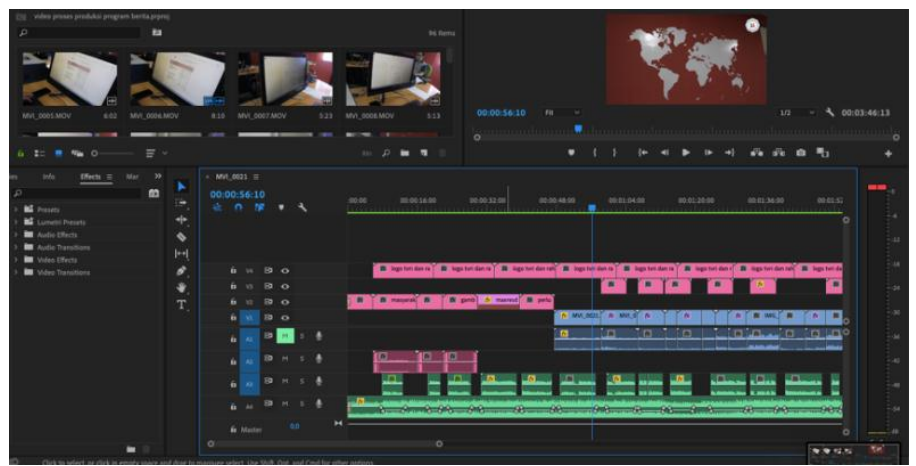

Gambar 19 Proses Mixing

\section{Finishing}

Finishing adalah tahap untuk menyempurnakan video. Tahapan ini seluruh video dan unsur pendukung lainnya seperti dubbing, backsound dan unsur lainnya akan dilakukan 
penyesuaian apakah seluruhnya sudah sesuai dengan konsep yang diinginkan. Serta apabila terdapat beberapa yang belum sesuai. Maka dapat disesuaikan sebelum masuk ke dalam tahapan exporting media video.

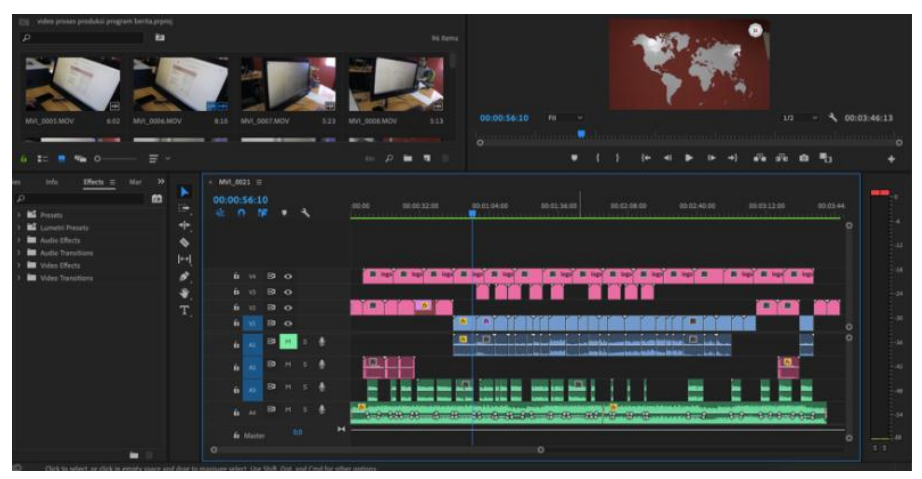

Gambar 20 Proses Finishing

\section{Exporting}

Tahapan exporting adalah tahapan akhir setelah melakukan digitalizing, editing, mixing dan finishing. Pada tahapan exporting maka kualitas video sudah sangat baik dan memiliki kualitas HD (High Definition). Sehingga media video yang telah di export dapat digunakan dan diupload di beberapa media sosial yang digunakan oleh TVRI khususnya program berita Klik Indonesia Malam.

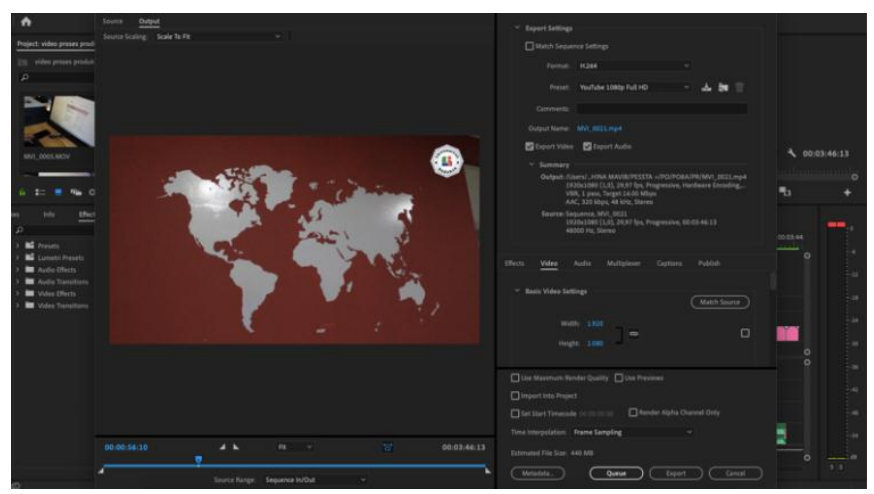

Gambar 21 Proses Exporting

\section{KESIMPULAN}

Adapun kesimpulan yang dapat dijelaskan oleh penulis adalah dengan sebuah rancangan media dalam berbentuk video profile yang menjelaskan mengenai program berita Klik Indonesia Malam yang ditayangkan setiap hari oleh TVRI. Maka akan memberikan informasi kepada masyarakat secara luas mengenai program berita Klik Indonesia Malam sebagai salah satu program berita yang menyajikan berita secara up to date dan cepat mengenai informasi di seluruh Indonesia yang menjelaskan berita seperti sosial, ekonomi, politik, budaya, olahraga dan lainnya.

\section{SARAN}

Adapun saran yang dapat diberikan oleh penulis adalah media video perlu dikembangkan menjadi konsep yang lebih menarik agar masyarakat dapat lebih tertarik mengenai program berita Klik Indonesia Malam sehingga dapat lebih dikenal luas oleh 
masyarakat serta dapat menjadi sebuah program berita yang selalu memberikan informasi yang up to date kepada masyarakat.

\section{DAFTAR PUSTAKA}

[1] Pratiwi, Ni Wayan Eviyanti Siska. 2018. Kemampuan Siswa Kelas Viii B SMP Negeri 1 Torue Dalam Menulis Teks Berita. Palu : Universitas Tadulako. Jurnal Bahasa Dan Sastra.Vol.3 No.4. Issn : 2302 - 2043. Hal. 52.

[2] Habibie, Dedi Kusuma. 2018. Dwi Fungsi Media Massa. Yogyakarta : Universitas Gadjah Mada. Jurnal Ilmu Komunikasi. Vol.7 No.2.

[3] Putra, Azwar Aditya dan Vella Carisa. 2019. Video Kabupaten Tangerang Pada Dinas Disporabudpar Pariwisata. Tangerang : Stmik Raharja. Jurnal Cices. Vol. 5 No.1 Hal. 70.

[4] Baqi, Puad Abudl. Anira Restuintina. Brian Reega Pantarezi. 2020. Media Video Iklan Dengan Teknologi Sistem CCTV Sebagai Promosi Pada PT. Lamjaya Inovasi Komputindo. Tangerang : Universitas Raharja. Jurnal Mavib. Vol.1 No.1. Hal. 5.

[5] Edison dan Reski Pulpi Tambes. 2019. Peran Editor Video Dalam Produksi Program Sembang Malam di Ceria TV Pekanbaru. Pekanbaru : Universitas Islam Negeri Sultan Syarif Kasim Riau. Jurnal Pemikiran Islam. Vol.43 No.1. Issn : 2407 - 1706. Hal.15.

[6] Wulandari, Nur Alfiana Dan Lukman Hakim. 2019. Produksi Program Jurnal 9 Pada TV9 Dalam Prespektif Media Islam. Surabaya : Universitas Islam Negeri Sunan Ampel. Jurnal Islamic Civilization. Vol.1 No.2. Hal 96.

[7] Roy, Yoissi dan Indah Suryawati. 2018. Strategi Produser Dalam Mempertahankan Program Acara "i Di Net TV. Jakarta : Universitas Budi Luhur.

[8] Ningsih, Listina Nadhia. Ray Tri Nugroho. I Nyoman Lingga Anjana. 2017. Produksi Program Music Chamber Dalam Bentuk Video Documenter Pada PT. Mata Air Inspirasi (Swana Fmtv). Tangerang : Stmik Raharja. Jurnal Icit. Vol.3 No.1. Issn : 2356 - 5159. Hal. 42.

[9] Nensir. Asni Djamereng. Hartina Sanusi. 2020. Produksi Siaran Langsung TVone Biro Makassar Dalam Program Apa Kabar Indonesia Pagi Edisi September 2019. Makassar : Uin Alauddin Makassar. Jurnal Wiashiyah. Vol.1 No.1. Hal. 213. 